Elsevier

MTR 04735

\title{
Genotoxicity of aniline derivatives in various short-term tests
}

\author{
M.E. Kugler-Steigmeier, U. Friederich, U. Graf, W.K. Lutz, P. Maier and Ch. Schlatter \\ Institute of Toxicology, Swiss Federal Institute of Technology and University of Zurich, CH-8603 Schwerzenbach (Switzerland)
}

(Received 1 September 1988)

(Revision received 11 November 1988)

(Accepted 14 November 1988)

Keywords: Aniline derivatives; Genotoxicity; Short-term tests; Covalent DNA binding

\section{Summary}

Various substituted aniline derivatives were tested for genotoxicity in several short-term tests in order to examine the hypothesis that a substitution at both ortho positions (2,6-disubstitution) could prevent genotoxicity due to steric hindrance of an enzymatic activation to electrophilic intermediates. In the Salmonella/microsome assay, 2,6-dialkylsubstituted anilines and 2,4,6-trimethylaniline (2,4,6-TMA) were weakly mutagenic in strain TA100 when $20 \%$ S9 mix was used, although effects were small compared to those of 2,4-dimethylaniline and 2,4,5-trimethylaniline (2,4,5-TMA). In Drosophila melanogaster, however, 2,4,6-TMA and 2,4,6-trichloroaniline (TCA) were mutagenic in the wing spot test at 2-3 times lower doses than 2,4,5-TMA. In the 6-thioguanine resistance test in cultured fibroblasts, 2,4,6-TMA was again mutagenic at lower doses than 2,4,5-TMA. Two methylene-bis-aniline derivatives were also tested with the above methods: 4,4'-methylene-bis-(2-chloroaniline) (MOCA) was moderately genotoxic in all 3 test systems whereas 4,4'-methylene-bis-(2-ethyl-6-methylaniline) (MMEA) showed no genotoxicity at all. DNA binding studies in rats, however, revealed that both MOCA and MMEA produced DNA adducts in the liver at levels typically found for moderately strong genotoxic carcinogens. These results indicate that the predictive value of the in vitro test systems and particularly the Salmonella/microsome assay is inadequate to detect genotoxicity in aromatic amines. Genotoxicity seems to be a general property of aniline derivatives and does not seem to be greatly influenced by substitution at both ortho positions.

Ortho,ortho-dialkylated anilines, in general, are reported to be non-genotoxic (Zimmer et al., 1980; Mulholland et al., 1983). The hypothesis was that a substitution at both ortho positions could prevent genotoxicity due to steric hindrance of the enzymatic oxidation of the aromatic amino group. This observation had been made earlier by various

\footnotetext{
Correspondence; Dr. U. Friederich, Institute of Toxicology, Swiss Federal Institute of Technology and University of Zurich, Schorenstr. 16, CH-8603 Schwerzenbach (Switzerland).
}

authors (Holland et al., 1974; Garner et al., 1975; Ashby, et al., 1982). Benzidine, for example, is genotoxic in most short-term tests (Ashby, 1981) and carcinogenic in mammals (Vesselinovitch et al., 1975; Nelson et al., 1982) while its analogue 3,3',5,5'-tetramethylbenzidine was not mutagenic in Salmonella, in yeast, or in higher eukaryotes in vivo and in vitro. In mammals, the latter was not carcinogenic at doses 100-1000 times higher than benzidine (Holland et al., 1974). It was suggested that this lack of genotoxicity was a result of steric hindrance by the 2 alkyl groups ortho to the amine 
group, as primary aromatic amines are known to need enzymatic activation to the corresponding hydroxylamine derivatives to express genotoxic activity. In contradiction to this hypothesis, however, 2,4,6-trimethylaniline (2,4,6-TMA) and 2,4,6-trichloroaniline (2,4,6-TCA) are carcinogenic in mammals (Russfield et al., 1973; Weisburger et al., 1978). The aim of this study was therefore to examine more closely the genotoxic properties of ortho,ortho-disubstituted aniline derivatives. If such compounds were indeed non-genotoxic, they would be of great interest for replacing genotoxic aniline derivatives, as aniline derivatives are nowadays widely used chemicals. This paper describes the results of several anilines tested in the Salmonella/microsome assay, in the somatic mutation and recombination test in Drosophila melanogaster, and in the 6-thioguanine resistance test in rat fibroblast cultures. Furthermore, the DNA binding of the 2 methylenedianilines 4,4'methylene-bis-(2-chloroaniline) (MOCA) and 4,4'-methylene-bis-(2-ethyl-6-methylaniline) (MMEA) in rats was determined.

\section{Materials and methods}

\section{Test compounds}

2,4-Dimethylaniline and 2,6-dimethylaniline were from Fluka, Buchs (Switzerland). 2-Ethyl-6methylaniline, 2,6-diethylaniline, 2-methyl-6-isopropylaniline, 2,6-diisopropylaniline, MMEA and MOCA were from Lonza AG, Basel (Switzerland). 2,4,5-Trimethylaniline (2,4,5-TMA) was from $\mathrm{K}+$ $\mathrm{K}$ Labs, Plainview, NY (U.S.A.), 2,4,6-TMA and 2,4,6-TCA were from EGA Chemie, Stammheim (F.R.G.). The purity of all compounds was checked by gas chromatography, and was in all cases $>$ 99\%. [Methylene $-{ }^{14} \mathrm{C}$ ]MOCA, with a specific activity of $216 \mu \mathrm{Ci} / \mathrm{mg}$, was purchased from Amersham (U.K.). Radiochemical purity, checked by thin-layer chromatography (TLC, cyclohexane + diethylether, $1+1)$, was $>98 \%$.

[Methylene- ${ }^{14} \mathrm{C}$ ]MMEA was synthesized by condensation of 2-ethyl-6-methylaniline (154 $\mu$ mole) with radiolabelled paraformaldehyde ( 73 $\mu$ mole) in $2 \mathrm{ml}$ xylene solution containing 2 drops of $\mathrm{H}_{2} \mathrm{SO}_{4} 25 \%$ at $145^{\circ} \mathrm{C}$ for $23 \mathrm{~h}$. After cooling the solution to $90^{\circ} \mathrm{C}, 3$ drops of $\mathrm{NaOH} 50 \%$ were added to $\mathrm{pH} 7.4$, and the mixture was extracted twice with water to remove unreacted paraformaldehyde. The yield of radioactive MMEA was 73\%. Its radiochemical purity, checked by TLC (toluene + acetone, $3+1$ ), was $>98 \%$.

\section{Salmonella / microsome assays}

Salmonella typhimurium strains TA98 and TA100 were provided by Dr. B.N. Ames (University of California, Berkeley, CA, U.S.A.). The S9 fraction $(9000 \times \mathrm{g}$ supernatant of liver homogenate of aroclor 1254-induced SD rats; $10-40 \%$ in the S9 mix) was prepared according to Ames et al. (1975). The liver $S 9$ fraction of aroclor-induced or non-induced Syrian hamsters was kindly supplied by Dr. S. Albertini, Hoffmann-LaRoche AG, Basel (Switzerland). The solvent for all test compounds was dimethyl sulfoxide (DMSO, 50 $\mu \mathrm{l} /$ plate). Tests were performed without preincubation following the methods of Ames et al. (1975), as pilot experiments with 2,4-dimethylaniline had shown that preincubation reduced the number of induced revertants in comparison to the standard plate incorporation protocol. The following modification was used: the ingredients for 3 replicate plates were mixed in the given order in a test tube $(6.0 \mathrm{ml}$ top agar, $1.5 \mathrm{ml} \mathrm{S} 9$ mix, $0.15 \mathrm{ml}$ DMSO containing the test compound, and $0.3 \mathrm{ml}$ bacteria); the suspension was vigorously shaken and 3 equal parts of the mixture were added on each of 3 replicate plates. Compounds were tested at various dose levels, the limiting factor in all cases was their solubility in the aqueous top agar. The presence of a background lawn of bacteria on the minimal medium plates was taken as an indicator of no gross toxic effects. Plates were used in triplicate to determine the number of revertants. For a comparison of the compounds, the relative mutagenicity was calculated: total number of revertants on treated plates divided by the number of revertants on the plates with solvent only.

Somatic mutation and recombination test in Drosophila melanogaster

72-h-old larvae of Drosophila melanogaster, trans-heterozygous for the mutations multiple wing hair (mwh, 3-0.0) and flare (flr, 3-38.8), were fed the test compounds for $48 \mathrm{~h}$. Test compounds were dissolved in an aqueous solution containing 
$3 \%$ absolute ethanol and $1 \%$ Tween 80 and used to prepare Drosophila Instant Medium (Formula 424, Carolina Biological Supply Company, Burlington, NC, U.S.A.). In order to determine the spontaneous mutation frequency, additional larvae were simultaneously exposed to the solvent only. The larvae were treated, and the wings prepared and scored for induced spots according to Graf et al. (1984). Statistical analysis of the data was carried out as described by Frei and Würgler (1988).

\section{6-Thioguanine resistance test in cultured rat fibro- blasts}

Fibroblasts were isolated from the upper inside of a subcutaneous air pouch (granuloma pouch assay, Maier, 1984), 4 days after the subcutaneous injection of $25 \mathrm{ml}$ of germ-free air into the loose connective tissue between the shoulder blades of 230-260-g (54 \pm 4 days old) male rats (Sprague-Dawley [Iva:SIV-50.SD], Ivanovas, Kissleg, F.R.G.) (Maier et al., 1987). Isolated cells were cultured in Dulbecco's minimum essential medium supplemented with $10 \%$ fetal calf serum and $0.5 \%$ gentamycin for 3 days, subsequently trypsinized, seeded, and exposed to the test agents after another $24 \mathrm{~h}$ in culture (pilot experiments) or they were exposed immediately after a 24-h culture period following isolation (subsequent experiments). Exposure intervals chosen were $7 \mathrm{~h}$ in the pilot experiments and $24 \mathrm{~h}$ in the subsequent experiments. After a 24 -h recovery period, cells were trypsinized, and subjected to a 6-day expression period. Mutant clones were recovered after a 7-day growth period in selective 6-thioguanine medium as described earlier (Maier et al., 1987). The solvents used were acetone for the 3 chemicals 2,4,5-TMA, 2,4,6-TMA and MOCA (1\% in the medium), and methanol for MMEA (1\% in the medium). Significance of the results was tested by the method of Kastenbaum and Bowman.

DNA binding in rat liver, lung, kidney, and bladder Both MOCA and MMEA were dissolved in $0.05 \mathrm{~N} \mathrm{HCl}$. In the case of MOCA, 2 application solutions were prepared that differed 10-fold in specific radioactivity, while MMEA was tested at only one dose level. Both compounds were administered to male 210-240-g Sprague-Dawley rats [Iva:SIV-50.SD] (Ivanovas, Kissleg, F.R.G.) by oral gavage. Chemical and radioactivity doses are presented in Table 4. Urine was collected for $4 \mathrm{~h}$. $20 \mathrm{~h}$ after administration, the animals were killed by heart puncture under ether anesthesia, and liver and lung were excised. The carcasses were frozen at $-20^{\circ} \mathrm{C}$. Later they were thawed to remove kidneys and bladder. Isolation and purification of DNA was performed essentially according to Sagelsdorff et al. (1983): preparation of a chromatin pellet by precipitation with a detergent, then homogenizing in lysing medium, deproteinating with phenol/chloroform/isoamyl alcohol, and extraction with ether. DNA was then purified by adsorption on a hydroxylapatite column, dialysed, and precipitated with ethanol. After dissolving pure DNA in buffer, the concentration was determined spectrophotometrically, the radioactivity of an aliquot was measured by scintillation counting, and the specific radioactivity calculated. If the DNA was radiolabelled, another purification round was performed involving deproteination, ether extraction, dialysis, precipitation with ethanol, and dissolving in buffer, to again determine the specific activity. Those DNA samples which contained more than a total of $50 \mathrm{cpm}$ were subjected to nucleotide analysis according to Sagelsdorff et al. (1988). DNA was enzymatically hydrolyzed to the 3 '-deoxynucleotides which were separated by high-performance liquid chromatography (HPLC). This made it possible to distinguish between radioactivity coeluting with the natural DNA constituents (i.e., radioactivity which had been biosynthetically incorporated into the nucleotides) and radioactivity eluting apart from natural DNA constituents (indicating covalently bound test compound).

In order to determine the possible contribution of radiolabelled protein to the radioactivity on the DNA (protein contamination can amount to $0.2 \%$ in DNA with the described DNA isolation method, as shown by Caviezel et al., 1984), radioactivity bound to protein was determined. This involved repeated precipitation of chromatin protein (from the phenol/chloroform/isoamyl alcohol extract) with acetone and dissolving in a detergent to constant radioactivity (Sagelsdorff et al., 1983). The specific activity was determined by scintillation counting of an aliquot after determination of the protein concentration by the Lowry method. 
DNA was isolated from a control rat which did not receive radioactivity in order to show that no radioactive contamination occurred during DNA isolation. The specific DNA activity attributable to covalent nucleotide-test compound adducts was expressed per administered dose and converted to the molar units of the 'covalent binding index' (CBI) (Lutz, 1979) as $\mu$ mole chemical bound per mole DNA nucleotide/mmole chemical administered per $\mathrm{kg}$ body weight.

\section{Results}

\section{Salmonella / microsome assays}

Experiments with 2,6-dimethylaniline in TA100 showed an increasing mutagenicity when the amount of rat liver homogenate in the $\mathrm{S} 9$ mix was elevated from $10 \%$ to $20 \%$. Therefore, all tests were carried out with 20\% S9 mix. 2,6-Dimethylaniline, 2-ethyl-6-methylaniline, 2,6-diethylaniline, and 2-isopropyl-6-methylaniline were all weakly mutagenic in strain TA100. The small dose-related increase in the relative mutagenicity was in all cases below a factor of 2 . With increasing chain length from ethyl to isopropyl a decrease in mutagenicity can be noted; 2,6-diisopropyl aniline was no longer mutagenic. Results are presented in Table 1. None of these compounds showed mutagenicity in strain TA98. Results with trisubstituted anilines are presented in Fig. 1a. 2,4,6-TMA gave significant dose-related mutagenic effects in TA100 which were, however, very weak compared to those of 2,4,5-TMA. Of the dianilines MMEA failed to give a positive result in TA98 or TA100 although various amounts of rat or Syrian hamster liver homogenate were used in the $\mathbf{S} 9 \mathrm{mix}$, whereas the simultaneously tested MOCA was positive in all experiments (Fig. 1b). Activation of MOCA by hamster instead of rat liver homogenate increased the mutagenicity.

Somatic mutation and recombination test in Drosophila melanogaster

Three trisubstituted anilines (2,4,5- and 2,4,6TMA and 2,4,6-TCA) as well as MOCA and MMEA, but not disubstituted derivatives, were investigated for genotoxicity in Drosophila. The trimethylanilines were both tested at 3 different concentrations. The results of all tested compounds are presented in Table 2. As 2,4,6-TMA was 2-3 times more toxic than 2,4,5-TMA for the larvae, it had to be tested at lower doses. Both compounds were positive for small single spots; large single and twin spots were not significantly different from controls. At $4 \mathrm{mM}, 2,4,6-\mathrm{TMA}$ showed a comparable genotoxicity to 2,4,5-TMA at $15 \mathrm{mM}$ while $2,4,6-\mathrm{TCA}$ at $5 \mathrm{mM}$ was slightly more genotoxic than 2,4,6-TMA. MOCA and MMEA were both tested at $5 \mathrm{mM}$ as higher doses were insoluble in the solvent. MOCA was weakly positive for small single spots but negative for large single spots and twin spots (Fig. 2a). MMEA was negative for all spot sizes at $5 \mathrm{mM}$ (Fig. 2b). As the twin spots were not different from controls, the figures show only the results of the single spots.

TABLE 1

MUTAGENICITY OF 2,6-DISUBSTITUTED ANILINES IN Salmonella typhimurium TA100 AFTER METABOLIC ACTIVATION WITH 20\% RAT LIVER HOMOGENATE IN THE S 9 MIX

To allow comparison, the results are presented as relative mutagenicity (total revertants of triplicate plates divided by spontaneous revertants). nd, no data. $t$, toxic for bacteria.

\begin{tabular}{|c|c|c|c|c|c|}
\hline \multirow{2}{*}{$\begin{array}{l}\text { Dose } \\
\text { ( } \mu \text { mole/plate) }\end{array}$} & \multicolumn{5}{|c|}{ Relative mutagenicity } \\
\hline & $\begin{array}{l}\text { Dimethyl- } \\
\text { aniline }\end{array}$ & $\begin{array}{l}\text { Methylethyl- } \\
\text { aniline }\end{array}$ & $\begin{array}{l}\text { Diethyl- } \\
\text { aniline }\end{array}$ & $\begin{array}{l}\text { Methylisopropyl- } \\
\text { aniline }\end{array}$ & $\begin{array}{l}\text { Diisopropyl- } \\
\text { aniline }\end{array}$ \\
\hline 4.1 & 1.21 & 1.02 & 1.30 & 1.15 & 0.97 \\
\hline 8.3 & 1.26 & 1.23 & 1.32 & 1.12 & 0.95 \\
\hline 12.4 & 1.36 & nd & 1.32 & 1.10 & $\mathrm{t}$ \\
\hline 16.5 & 1.39 & 1.51 & $t$ & $t$ & \\
\hline 24.6 & 1.48 & 1.52 & & & \\
\hline 33.1 & 1.43 & t & & & \\
\hline
\end{tabular}



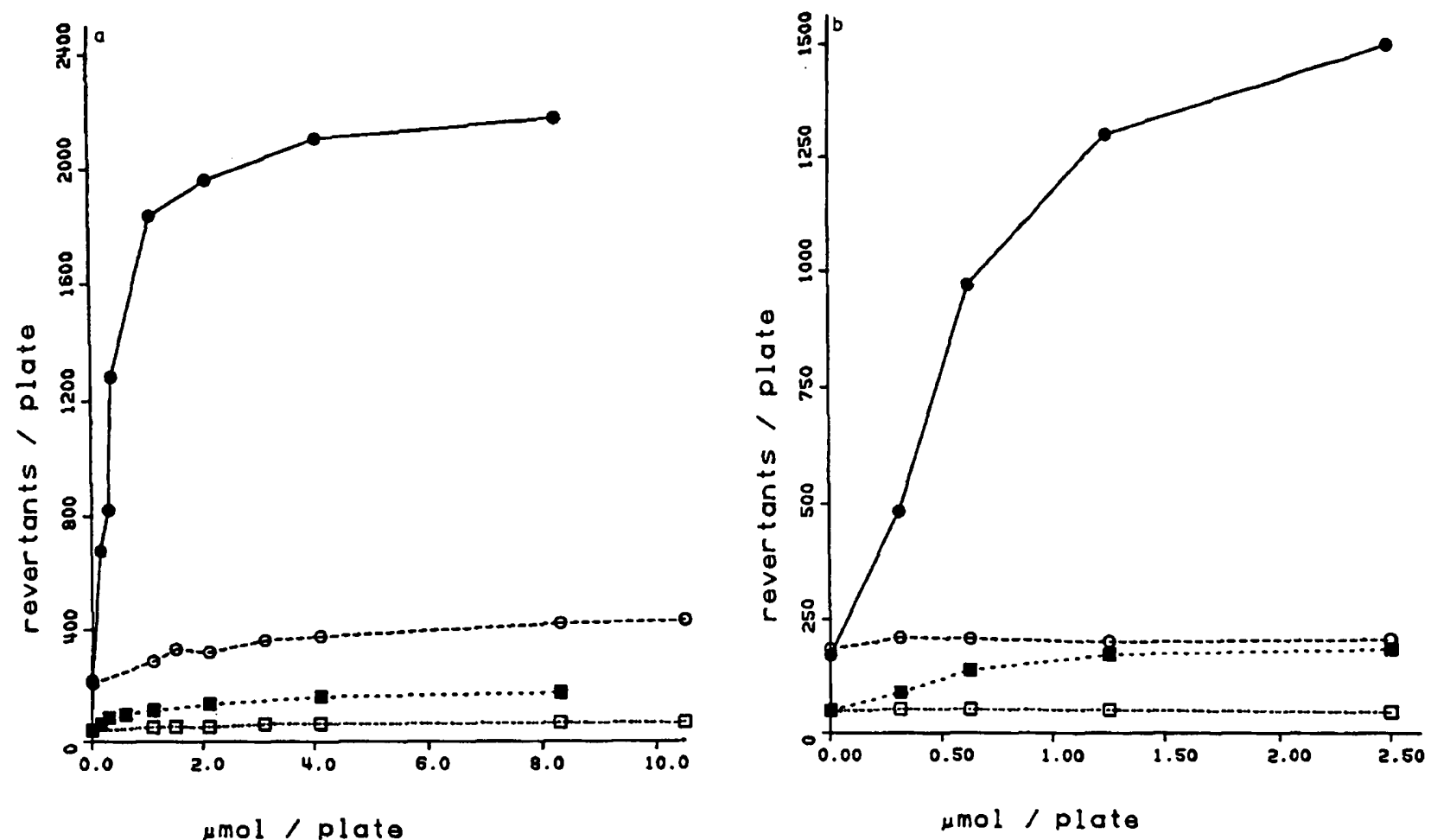

Fig. 1. (a) Mutagenicity of 2,4,5- and 2,4,6-trimethylaniline (TMA) in Salmonella typhimurium TA98 and TA100 after metabolic activation with $20 \%$ rat liver homogenate in the S9 mix. Total number of revertants per plate as mean of triplicates. 2,4,5-TMA in TA100, $0 \ldots . .0$ 2,4,6-TMA in TA100, $\ldots$ 2,4,5-TMA in TA98, $-. .-2,4,6-$ TMA in TA98. (b) Mutagenicity of MOCA and MMEA in Salmonella typhimurium TA98 and TA100 after metabolic activation with 20\% rat liver homogenate in the $S 9$ mix. Total number of revertants per plate as mean of triplicates. $-\longrightarrow$ MOCA in TA100, $0 \ldots \ldots$ MMEA in TA100, $\ldots . . .-$ MOCA in TA98, $\square . . .-\square$ MMEA in TA98.

6-Thioguanine resistance test in rat fibroblast cultures

Pilot experiments showed that freshly isolated (as opposed to subcultured) fibroblasts, incubated at $19 \% \mathrm{O}_{2}$ (as opposed to $5 \% \mathrm{O}_{2}$ ), were most sensitive for testing aniline derivatives. Treatment of the cells with the test compound for 24 rather

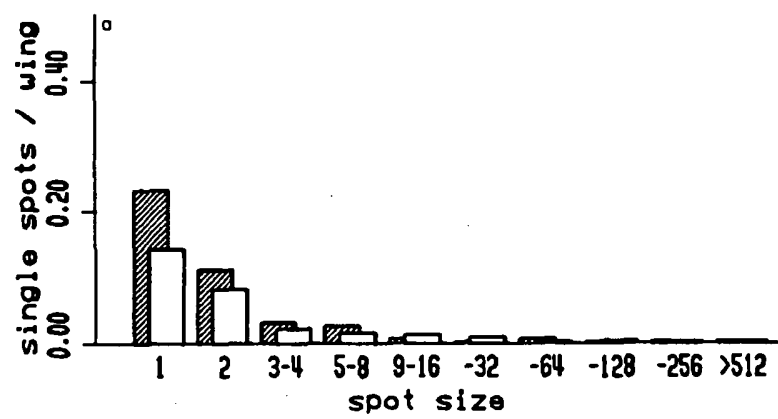

than $7 \mathrm{~h}$ further increased the number of mutants. Experiments were carried out in a dose range of 74-740 $\mu$ mole test compound per ml medium for 2,4,5-TMA, and of 37-148 $\mu \mathrm{mole} / \mathrm{ml}$ for $2,4,6-$ TMA, as 2,4,6-TMA was rather toxic for the cells. 2,4,6-TMA showed the maximum rate of mutants at $74 \mu \mathrm{mole} / \mathrm{ml}$ whereas for $2,4,5-\mathrm{TMA}$ the maxi-

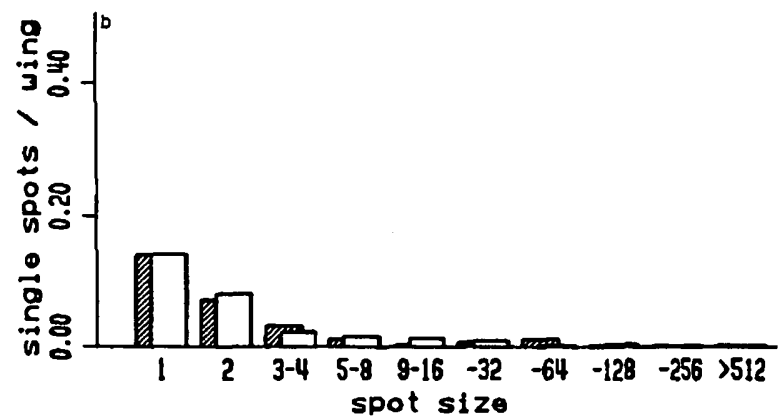

Fig. 2. Single wing spots induced by $48 \mathrm{~h}$ treatment of 72 -h-old trans-heterozygous larvae of Drosophila melanogaster with $5 \mathrm{mM}$ MOCA (a) and 5 mM MMEA (b). Open bars: controls ( 442 wings); hatched bars: treated series (200 wings). 
TABLE 2

WING SPOTS INDUCED BY 48-h TREATMENT OF 72-h-old TRANS-HETEROZYGOUS LARVAE OF Drosophila melanogaster

\begin{tabular}{|c|c|c|c|c|c|}
\hline \multirow{2}{*}{$\begin{array}{l}\text { Compound } \\
\text { concentration }\end{array}$} & \multirow{2}{*}{$\begin{array}{l}\text { Number } \\
\text { of wings }\end{array}$} & \multicolumn{4}{|c|}{ Spots per wing and statistical diagnoses ${ }^{a}$} \\
\hline & & $\begin{array}{l}\text { small } \\
\text { single } \\
\text { spots } \\
\mathbf{m}=2.0\end{array}$ & $\begin{array}{l}\text { large } \\
\text { single } \\
\text { spots } \\
\mathrm{m}=5.0\end{array}$ & $\begin{array}{l}\text { twin } \\
\text { spots } \\
\mathrm{m}=5.0\end{array}$ & $\begin{array}{l}\text { total } \\
\text { spots } \\
\mathrm{m}=2.0\end{array}$ \\
\hline Control & 442 & 0.22 & 0.05 & 0.01 & 0.28 \\
\hline $\begin{array}{l}2,4,5-T M A \\
10 \mathrm{mM} \\
15 \mathrm{mM} \\
20 \mathrm{mM}\end{array}$ & $\begin{array}{l}136 \\
160 \\
184\end{array}$ & $\begin{array}{l}0.33+ \\
0.41+ \\
0.57+\end{array}$ & $\begin{array}{l}0.06- \\
0.08- \\
0.07-\end{array}$ & $\begin{array}{l}0.01 \mathrm{i} \\
0.03 \mathrm{i} \\
0.03 \mathrm{i}\end{array}$ & $\begin{array}{l}0.40+ \\
0.52+ \\
0.66+\end{array}$ \\
\hline $\begin{array}{l}2,4,6-\mathrm{TMA} \\
2 \mathrm{mM} \\
4 \mathrm{mM} \\
6 \mathrm{mM}\end{array}$ & $\begin{array}{r}90 \\
120 \\
160\end{array}$ & $\begin{array}{l}0.21- \\
0.37+ \\
0.37+\end{array}$ & $\begin{array}{l}0.08- \\
0.10 w \\
0.09-\end{array}$ & $\begin{array}{l}0.01 \mathrm{i} \\
0.01 \mathrm{i} \\
0.03 \mathrm{i}\end{array}$ & $\begin{array}{l}0.30- \\
0.47+ \\
0.48+\end{array}$ \\
\hline $\begin{array}{l}2,4,6-T C A \\
5 \mathrm{mM}\end{array}$ & 80 & $0.45+$ & $0.08-$ & $0.01 \mathrm{i}$ & $0.54+$ \\
\hline $\begin{array}{l}\text { MOCA } \\
5 \mathrm{mM}\end{array}$ & 200 & $0.34+$ & $0.06-$ & $0.01-$ & $0.42 w$ \\
\hline $\begin{array}{l}\text { MMEA } \\
5 \mathrm{mM}\end{array}$ & 240 & $0.21-$ & $0.05-$ & $0.00-$ & $0.26-$ \\
\hline
\end{tabular}

a Statistical diagnoses according to Frei and Würgler (1988). +, positive; - , negative; w, weak; i, inconclusive. Probability levels $\alpha=\beta=0.05$. One-sided statistical tests. Small single spots, 1-2 cells; large single spots, $>2$ cells. $\mathrm{m}$, multiplication factor.

mum rate was at $148 \mu \mathrm{mole} / \mathrm{ml}$. No dose response was obtained, which is considered to be due mainly to a toxic or growth-inhibiting activity of the chemicals. Results are summarized in Table 3.

Treating freshly isolated fibroblasts with 35-364 nmole MMEA per ml medium resulted in no mutant clones in 2 independent experiments. MOCA tested in the same dose range induced 2 mutants per $10^{6}$ cells at $36 \mathrm{nmole} / \mathrm{ml}$ medium (not significantly different from control) and 4 mutants per $10^{6}$ cells at $72 \mathrm{nmole} / \mathrm{ml}$ medium. In a second identical test no clones could be detected.

\section{DNA binding of MOCA and MMEA}

The amount of radioactivity excreted in the urine during $4 \mathrm{~h}$ following oral application was $17 \%$ in the MOCA high-dosed rats, $10 \%$ in the MOCA low-dosed rats, and $8 \%$ in the rats treated with MMEA. When the rats were killed after $20 \mathrm{~h}$,
$2 \%$ of the administered radioactivity was found in the liver, $0.13-0.19 \%$ in the blood, $0.10-0.15 \%$ in the kidneys, and less than $0.01 \%$ in the bladder. In the lung, a marked difference was noted between the MOCA- and the MMEA-treated animals: $0.03-0.09 \%$ of labelled MOCA (or metabolites) was found versus $0.016 \%$ of labelled MMEA (or metabolites). The results with MOCA agree with those found by Farmer et al. (1981) and Tobes et al. (1983).

From the first to the second DNA purification the specific activity was either constant or not significantly decreased, so that a third purification round was not necessary. In order to distinguish between biosynthetic incorporation of radioactive fragments into the DNA and genuine covalent binding, DNA was enzymatically degraded to the nucleotides which were separated by HPLC. The specific radioactivity of the MOCA liver and lung DNA and MMEA liver DNA was sufficiently high $(52-320 \mathrm{dpm} / \mathrm{mg})$ to allow for this analysis. 
TABLE 3

\section{6-THIOGUANINE RESISTANCE TEST}

Induction of mutations after $24 \mathrm{~h}$ in vitro exposure of fibroblasts to 2,4,5- and 2,4,6-trimethylaniline (TMA), and 4,4'-methylene-bis(2-chloroaniline) (MOCA), and 4,4'-methylene-bis-(2-ethyl-6-methylaniline) (MMEA). nd, no data. -, no clones detected, resulting in a mutant frequency below 1.1-4.4 (depending on the number of cells tested).

\begin{tabular}{|c|c|c|c|c|c|c|}
\hline \multirow{2}{*}{$\begin{array}{l}\text { Compound } \\
\text { concentration } \\
(\mu \mathrm{g} / \mathrm{ml} \text { medium) }\end{array}$} & \multicolumn{2}{|c|}{$\begin{array}{l}\text { Cloning efficiency } \\
\text { (\%) }\end{array}$} & \multicolumn{2}{|c|}{$\begin{array}{l}\text { Clone forming cells } \\
\text { tested } \cdot 10^{5}\end{array}$} & \multicolumn{2}{|c|}{$\begin{array}{l}\text { Mutant frequency } \\
\text { (mean } \cdot 10^{-6} \text { ) }\end{array}$} \\
\hline & expt. 1 & expt. 2 & expt. 1 & expt. 2 & expt. 1 & expt. 2 \\
\hline \multicolumn{7}{|l|}{$2,4,5-\mathrm{TMA}$} \\
\hline 74 & 75 & nd & 9.00 & nd & - & nd \\
\hline 148 & 74 & 52 & 8.88 & 6.24 & 11.3 & 8.0 \\
\hline 370 & 64 & 46 & 5.12 & 5.52 & 3.9 & $1.8^{\mathrm{a}}$ \\
\hline 740 & 63 & nd & 4.41 & nd & - & nd \\
\hline \multicolumn{7}{|l|}{ 2,4,6-TMA } \\
\hline 37 & 69 & 60 & 8.28 & 7.20 & $1.2^{\mathrm{a}}$ & $1.4^{\mathrm{a}}$ \\
\hline 74 & 62 & 51 & 7.44 & 6.12 & 6.7 & 4.9 \\
\hline 148 & 64 & 56 & 7.68 & 6.72 & 2.6 & - \\
\hline Control & 91 & 72 & 9.10 & 8.64 & - & 1.2 \\
\hline \multicolumn{7}{|l|}{ MOCA } \\
\hline 36 & 56 & 50 & 5.04 & 6.00 & $2.0^{a}$ & - \\
\hline 72 & 47 & 41 & 3.76 & 4.92 & 4.0 & - \\
\hline 181 & 39 & 40 & 3.12 & 4.80 & - & - \\
\hline 362 & 41 & 36 & 4.10 & 4.32 & - & - \\
\hline \multicolumn{7}{|l|}{ MMEA } \\
\hline 36 & 59 & 52 & 4.72 & 6.24 & - & - \\
\hline 72 & 51 & 46 & 4.08 & 5.52 & - & - \\
\hline 177 & 49 & 45 & 4.41 & 5.40 & - & - \\
\hline 364 & 38 & 40 & 2.28 & 4.80 & - & - \\
\hline Control & 63 & 80 & 7.56 & 8.80 & - & 1.5 \\
\hline
\end{tabular}

a Not significantly different from control (method of Kastenbaum and Bowman, probability levels $\alpha=\beta=0.05$, one-sided statistical tests).

In all 3 samples, 2 peaks of radioactivity eluted after the natural nucleotides, at retention times normally seen with lipophilic nucleotide-carcinogen adducts. These putative adducts all had different retention times and were therefore probably all structurally unique. In the liver and in the lung of the MOCA-treated animals $75 \%$ and $87 \%$ of the radioactivity, respectively, was covalently bound to DNA, and in the liver of the MMEA-treated animals $98 \%$ of the radioactivity was covalently bound. In order to compare the DNA binding ability of MOCA and MMEA with other substances, CBI values were calculated. The values ranged from 17 to 35 in liver, 1.4 to 72 in lung, 4 in kidney, and were below the limit of detection in the bladder (Table 4). There was a marked dif- ference between MOCA and MMEA only in binding to lung DNA: MOCA produced 30-50 times more adducts than did MMEA. In the other organs the effects of the compounds were comparable. With both test compounds, the radioactivity of bladder DNA was not significantly different from control values. Because of the small amount of bladder DNA, the detection limit was at a CBI value of 4 .

The specific activity of chromatin protein isolated from the lung was at about the same level as for DNA with both MOCA and MMEA. In liver, kidney, and bladder protein had a 5-10 times higher specific activity. As the maximum possible contamination of the DNA preparations with protein was less than 0.2\% (Caviezel et al., 1984), this 
TABLE 4

COVALENT BINDING OF [METHYLENE- ${ }^{14}$ C]LABELLED 4,4'-METHYLENE-BIS-(2-CHLOROANILINE) (MOCA) AND 4,4'-METHYLENE-BIS-(2-ETHYL-6-METHYLANILINE) (MMEA) TO DNA IN MALE SPRAGUE-DAWLEY RATS, $20 \mathrm{~h}$ FOLLOWING ORAL GAVAGE

\begin{tabular}{|c|c|c|c|c|c|c|}
\hline \multirow{2}{*}{$\begin{array}{l}\text { Test compound } \\
\text { Dose level }\end{array}$} & \multicolumn{4}{|c|}{ MOCA } & \multicolumn{2}{|c|}{ MMEA } \\
\hline & Low & & High & & High & \\
\hline $\begin{array}{l}\text { Chemical dose } \\
(\mathrm{mg} / \mathrm{kg})\end{array}$ & 1.43 & 2.32 & 28.1 & 29.6 & 31.6 & 29.3 \\
\hline $\begin{array}{l}\text { Radioactivity } \\
\qquad\left(10^{8} \mathrm{dpm} / \mathrm{kg}\right)\end{array}$ & 6.13 & 11.9 & 14.5 & 15.3 & 16.8 & 15.5 \\
\hline $\begin{array}{l}\text { DNA binding po } \\
\text { Liver } \\
\text { Lung } \\
\text { Kidney } \\
\text { Bladder }\end{array}$ & $\begin{array}{l}\text { I value } \\
20^{b} \\
71 b \\
\text { nd }\end{array}$ & $\begin{array}{r}17^{b} \\
72^{b} \\
\leqq 4^{c}\end{array}$ & $\begin{array}{l}33^{a} \\
41^{a} \\
\text { nd }\end{array}$ & $\begin{array}{r}23^{\mathrm{b}} \\
34^{\mathrm{b}} \\
\leqq 4^{\mathrm{c}}\end{array}$ & $\begin{array}{l}34^{\mathrm{a}} \\
\leqq 1.4^{\mathrm{c}} \\
\text { nd }\end{array}$ & $\begin{array}{l}35^{\mathrm{b}} \\
\leqq \\
\mathrm{g}^{\mathrm{c}} \\
4^{\mathrm{c}}\end{array}$ \\
\hline
\end{tabular}

nd, no data.

an the basis of nucleotide analyses.

b Percent adduct formation taken from nucleotide analysis a.

c No nucleotide analysis possible; upper limit value derived from specific activity of DNA.

DNA of 2 animals pooled. Specific activity of DNA below limit of detection.

The covalent binding index (CBI) is defined as:

$\mathrm{CBI}=\frac{\mu \text { mole chemical bound } / \text { mole DNA nucleotide }}{\text { mmole chemical applied } / \mathrm{kg} \text { body weight }}$

$\mathrm{CBI}=\frac{\mathrm{dpm} / \mathrm{mg} \text { DNA }}{\mathrm{dpm} / \mathrm{kg} \text { body weight }} \times 3.09 \times 10^{8}$

contribution to the DNA radioactivity can be ignored.

\section{Discussion}

\section{Salmonella / microsome assays}

Tests with 2,6-disubstituted compounds showed, in contrast to reports in the literature, weak mutagenicity when $20 \%$ instead of $10 \%$ rat liver homogenate was used as the activation system. The relative mutagenicity varied between 1.10 and 1.52. These weak effects are interpreted as positive because (1) they were reproducible, (2) the increase could be observed with at least 3 different doses, and (3) at least for 2,6-dimethylaniline and 2-methyl-6-ethylaniline there was a certain dose-effect relationship (weak increase of the relative mutagenicity with increasing dose).

Increase of the length of the side chain in the ortho positions resulted in decreased mutagenicity (2,6-diisopropylaniline was negative at the tested doses). The same effect has been seen in a series of phenylenediamines with alkyl or alkoxy substituents (Shahin et al., 1983). 2,6-Dialkylanilines with longer side chains showed increased bactericidal effects together with a decreased mutagenicity.

Somatic mutation and recombination test in Drosophila melanogaster

In Drosophila the test compounds tended to induce mainly small spots, which suggests that the somatic mutations were induced late in the development of the larvae, at a time point where only 1-2 more cell divisions took place. This phenomenon can be explained by the increasing activity of the metabolizing enzymes in the course of the development of the larvae (Hällström et al., 1983). From the absence of induced twin spots it can be concluded that the compounds do not exhibit strong recombinogenic activity. When MOCA and MMEA were tested, problems arose because of their low solubility in the aqueous solvent. The 
maximum possible concentration was $5 \mathrm{mM}$. MOCA was weakly positive at this dose level whereas MMEA was negative.

\section{6-Thioguanine resistance test in rat fibroblast cul- tures}

The experiments with fibroblasts in culture showed the importance of adequate activation of the aniline derivatives to reactive metabolites. Modifications which could improve oxidative activation increased the sensitivity of the test: freshly isolated fibroblasts usually have a higher enzyme activity than subcultured ones, exposure of the fibroblasts to the test compounds for 24 rather than $7 \mathrm{~h}$ allow a more complete metabolization, and incubation at $21 \%$ instead of $5 \% \mathrm{O}_{2}$ provides more oxygen for oxidative metabolism. It can be concluded that the activation mechanism in mammalian cells for anilines is not stable under in vitro conditions. Therefore handling of the freshly isolated cells, culture conditions, and culture time will affect the activation of anilines. This might explain why the positive results of MOCA could not be reproduced in a second experiment. The decrease of mutagenicity at high dose levels in the thioguanine test can be explained by the possible interference of anilines with prostaglandin synthesis which in turn affects DNA synthesis and mutation fixation (Maier and Schawalder, 1988).

\section{DNA binding in the rat}

The DNA binding experiments in rats showed comparable CBI values for MOCA and MMEA in the liver. The differences of the liver CBI between the 2 dose groups of MOCA was in the range of animal-to-animal variations. A liver CBI of 20-30, as was also reported by Silk and Martin (1986) for MOCA, is typically found for weak to moderately strong carcinogens. Using the linear correlation shown by Lutz (1986) between CBI and tumorigenic potency in vivo $\left(\mathrm{TD}_{50}\right.$, Gold et al., 1984), this CBI level would correspond to a $\mathrm{TD}_{50}$ of about $0.2 \mathrm{mmole} / \mathrm{kg}$ body weight/day, which correlates well with carcinogenicity data for MOCA $(10 \mathrm{mg} / \mathrm{kg} /$ day to induce a $50 \%$ liver tumor incidence in CD rats; Gold et al., 1984). In the lung there was a significant difference in DNA binding between MOCA and MMEA: MOCA was 30-50 times stronger than MMEA. This suggests that
MMEA (which has not been tested for carcinogenicity) might be less likely than MOCA to cause lung tumors. In MOCA, lung DNA binding was higher than that of liver, in agreement with the finding that MOCA effectively induces lung tumors (Kommineni et al., 1978). These authors judged the lung to be the most sensitive organ for tumor formation by MOCA. The activation of MOCA to DNA reactive metabolites probably takes place in the lung and is saturable in this tissue, as the CBI is markedly lower in the lung at the high dose level. The DNA binding in kidney and bladder was very low or not detectable for both MOCA and MMEA so that significant tumor formation in these organs appears unlikely.

\section{Structure-activity relationships}

The hypothesis that aniline derivatives could be rendered innocuous by substituting both ortho positions was not confirmed by this work. Eight out of 9 investigated compounds tested were genotoxic in one or more systems. In addition, recent data from the National Toxicology Program showed that 2,6-dimethylaniline induced tumors in rats at about the same dose level as does 2,4,5-TMA. This is in strong contrast to the data with Salmonella, where 2,6-dimethylaniline was about 20 times less mutagenic than 2,4,5-TMA.

The above quantitative differences between the Salmonella/microsome assay and the other tests used in the present studies are illustrated even better with 2,4,5-TMA and 2,4,6-TMA. 2,4,6-TMA was about 20 times less mutagenic than 2,4,5TMA, although it was 5-10 times more potent in evoking tumors. It seems, therefore, that the Salmonella/microsome assay underestimates the genotoxicity of di-ortho-substituted compounds in mammals. The data obtained with Drosophila and fibroblasts in culture, on the other hand, agree with the potency ranking seen in the carcinogenicity bioassay in rodents. The similarity of the results of tests using Drosophila and fibroblasts in culture had not been expected, because in the latter the compounds are probably activated via prostaglandin synthase pathways (Maier, 1984), while in Drosophila the activation depends mainly on cytochrome P-450 (Baars et al., 1977). While the Drosophila data with 2,4,5- and 2,4,6-TMA seem to correlate with tumorigenic potency in a 
quantitative manner, this test system ranked 2,4,6TCA about equally with 2,4,6-TMA. The carcinogenicity bioassay data, however, showed that 2,4,6-TCA was about 5 times less potent than the methyl analogue. These results indicate that one must be careful in attempting quantitative extrapolations.

MMEA was an even more extreme case: MMEA was negative not only in the Salmonella/microsome assay, but also in the somatic mutation and recombination test in Drosophila and in the 6thioguanine resistance test in rat fibroblast cultures. However, it produced covalent binding to rat liver DNA at about the same level as the proven carcinogen MOCA.

A literature survey (Kugler-Steigmeier, 1988, available upon request) showed that di- and trisubstituted aniline derivatives with one free ortho position are generally mutagenic and carcinogenic. Negative results in the Salmonella/microsome assay were found for monosubstituted as well as for 2,6-di- and 2,4,6-tri-substituted compounds. In the case of the monosubstituted anilines, the results were somewhat confusing, as a few authors reported a weak mutagenicity in substances that were classified as negative by others. Therefore, several conclusions published in the past appear to be unreliable.

In considering the present experiments as well as the reports in the literature, one must conclude that no class of aniline derivatives can be considered non-genotoxic. A quantitative prediction was poor with the Salmonella/microsome assay, more satisfactory with Drosophila and rat fibroblasts in vitro. A DNA binding study in an intact mammalian organism probably reflects the complicated enzymatic activation and inactivation processes most closely (Lutz, 1986). Since genotoxicity appears to be a general characteristic of aniline derivatives, and hence quantitative data are needed for risk assessment, such quantitative in vivo covalent binding studies might therefore be preferred over qualitative results from other short-term tests.

\section{References}

Ames, B.N., J. McCann and E. Yamasaki (1975) Methods for detecting carcinogens and mutagens with the Salmonella/mammalian microsome mútagenicity test, Mutation Res., 31, 347-364.
Ashby, J. (1981) Overview of study and test chemical activities, in: F.J. de Serres and J. Ashby (Eds.), Evaluation of Short-term Tests for Carcinogens, Vol. 1, Elsevier, Amsterdam, pp. 112-171.

Ashby, J., D. Paton, P.A. Lafevre, J.A. Styles and F.L. Rose (1982) Evaluation of two suggested methods of deactivating organic carcinogens by molecular modification, Carcinogenesis, 3, 1277-1282.

Baars, A.J., J.A. Zijlstra, E. Vogel and D.D. Breimer (1977) The occurrence of cytochrome P-450 and arylhydrocarbon hydroxylase activity in Drosophila melanogaster microsomes, and the importance of this metabolizing capacity for the screening of carcinogenic and mutagenic properties of foreign compounds, Mutation Res., 44, 257-268.

Caviezel, M., W.K. Lutz, U. Minini and Ch. Schlatter (1984) Interaction of estrone and estradiol with DNA and protein of liver and kidney in rat and hamster in vivo and in vitro, Arch. Toxicol., 55, 97-103.

Farmer, P.B., J. Rickard and S. Robertson (1981) The metabolism and distribution of 4,4'-methylene-bis-(2-chloroaniline) (MBOCA) in rats, J. Appl. Toxicol., 1, 317-332.

Frei, H., and F.E. Würgler (1988) A statistical method to decide whether mutagenicity test data from Drosophila assays indicate positive, negative, or inconclusive results, Mutation Res., 203, 297-308.

Garner, R.C., A.L. Walpole and F.L. Rose (1975) Testing of some benzidine analogues for microsomal activation to bacterial mutagens, Cancer Lett., 1, 39-42.

Gold, L.S., C.B. Sawyer, R. Magaw, G.M. Backman, M. de Veciana, R. Levonson, N.K. Hooper, W.R. Havender, L. Bernstein, R. Peto, M.C. Pike and B.N. Ames (1984) A carcinogenic potency database: standardized results of animal bioassays published through December 1982, Environ. Health Perspect., 67, 161-200.

Graf, U., F.E. Würgler, A.J. Katz, H. Frei, H. Juon, C.B. Hall and P.G. Kale (1984) Somatic mutation and recombination test in Drosophila melanogaster, Environ. Mutagen., 6, 153-188.

Hällström, I., A. Blanck and S. Atuma (1983) Comparison of cytochrome P-450 dependent metabolism in different development stages of Drosophila melanogaster, Chem.-Biol. Interact., 46, 39-54.

Holland, V.R., B.C. Saunders, F.L. Rose and A.L. Walpole (1974) A safer substitute for benzidine in the detection of blood, Tetrahedron, 30, 3299-3302.

Kommineni, C., D.H. Groth, I.J. Frockt, R.W. Voelker and R.P. Stanovick (1978) Determination of the tumorigenic potential of methylene-bis-orthochloroaniline, J. Environ. Path. Toxicol., 2, 149-171.

Kugler-Steigmeier, M.E. (1988) Erfassung der Genotoxizität von Anilin-Derivaten mit verschiedenen Testsystemen, Diss. ETH Nr. 8467.

Lutz, W.K. (1979) In vivo covalent binding of organic chemicals to DNA as a quantitative indicator in the process of chemical carcinogenesis, Mutation Res., 65, 289-356.

Lutz, W.K. (1986) Quantitative evaluation of DNA binding data for risk estimation and for classification of direct and indirect carcinogens, J. Cancer Res. Clin. Oncol., 112, $85-91$. 
Maier, P. (1984) The granuloma pouch assay, in: F.J. de Serres (Ed.), Chemical Mutagens, Principles and Methods for Their Detection, Vol. 9, Plenum Press, New York, London, pp. 233-260.

Maier, P., and H.P. Schawalder (1988) Hepatocarcinogens induce gene mutations in rats in fibroblast-like cells from a subcutaneous granulation tissue, Carcinogenesis, 9, 1363-1368.

Maier, P., H.P. Schawalder and B. Weibel (1987) Low oxygen tension, as found in tissues in vivo, alters the mutagenic activity of aristolochic acid I and II in primary fibroblastlike rat cells in vitro, Environ. Mol. Mutagen., 10, 275-284.

Mulholland, A., T.G. Pullin and G.L. TerHaar (1983) The mutagenicity of ring-substituted aniline compounds, Environ. Mutagen., 5, 443.

Nelson, C.J., K.P. Baetcke, C.H. Frith, R.L. Kodell and G. Schieferstein (1982) The influence of sex, dose, time, and cross on neoplasia in mice given benzidine dihydrochloride, Toxicol. Appl. Pharmacol., 64, 171-186.

Russfield, A.B., E. Boger, F. Homburger, E.K. Weisburger and J.H. Weisburger (1973) Effects of structure of seven methylanilines on toxicity and on incidence of subcutaneous and liver tumors in Charles River rats, Fed. Proc., 32, 833.

Sagelsdorff, P., W.K. Lutz and Ch. Schlatter (1983) The relevance of covalent binding to mouse liver DNA to the carcinogenic action of hexachlorocyclohexane isomers, Carcinogenesis, 4, 1267-1273.
Sagelsdorff, P., W.K. Lutz and Ch. Schlatter (1988) DNA methylation in rat liver by daminozide, 1,1-dimethylhydrazine, and dimethylnitrosamine, Fund. Appl. Toxicol., $11,723-730$

Shahin, M.M., A Bugaut and G. Kalopissis (1983) Relationships between the chemical structure and mutagenic activity of monocyclic aromatic amines, Chem. Mutagen., 8, 151-181.

Silk, N.A., and C.N. Martin (1986) Covalent adducts formed between methylenebis(o-chloroaniline) (MOCA) and DNA, Mutagenesis, 1, 389.

Tobes, M.C., L.E. Brown, B. Chin and D.D. Marsh (1983) Kinetics of tissue distribution and elimination of $4,4^{\prime}$-methylene-bis-(2-chloroaniline) in rats, Toxicol. Lett., 17, 69-75.

Vesselinovitch, S.D., K.V.N. Rao and N. Mihailovich (1975) Factors modulating benzidine carcinogenicity bioassay, Cancer Res., 35, 2814-2819.

Weisburger, E.K., A.B. Russfield, F. Homburger, J.H. Weisburger, E. Boger, C.G. Van Dongen and K.C. Chu (1978) Testing of twenty-one environmental aromatic amines or derivatives for long-term toxicity or carcinogenicity, J. Environ. Path. Toxicol., 2, 325-356.

Zimmer, D., J. Mazurek, G. Petzold and B.K. Bhuyan (1980) Bacterial mutagenicity and mammalian cell DNA damage by several substituted anilines, Mutation Res., 77, 317-326. 